\title{
DOES THE BOARD INDEPENDENCE INFLUENCE THE ASSOCIATION BETWEEN RISK DISCLOSURE AND FIRM VALUE? EVIDENCE FROM JORDAN
}

\author{
Mohammed Hassan Makhlouf $^{1^{*}}$, Yazan Oroud ${ }^{2}$, Mohammed Zakaria Soda ${ }^{3}$ \\ ${ }^{1 * 2,3}$ Accounting Department, Faculty of Business, Isra University, Jordan. \\ Email: ${ }^{1 *}$ mohammed.makhlouf@iu.edu.jo, ${ }^{2}$ oroud.yazan@iu.edu.jo, ${ }^{3}$ zakaria.soda@iu.edu.jo \\ Article History: Received on $22^{\text {nd }}$ February 2020, Revised on $29^{\text {th }}$ May 2020, Published on $4^{\text {th }}$ July 2020
}

\begin{abstract}
Purpose of the study: This paper aimed to investigate the influence of risk disclosure on corporate value and investigate whether the effect of risk disclosure on corporate value is moderated by the level of independence of boards of directors.

Methodology: Using an analysis of annual reports, the study depended on a set of balanced panel data derived from $\mathbf{1 3}$ banks listed on the "Amman Stock Exchange" (ASE) from 2014 to 2018.

Main Findings: The empirical results indicated that the association between risk disclosure and the corporate value was significant but negative. To examine the influence of the moderating variable, hierarchical regression models were used. The results regarding the moderating effect indicate that board independence (BI) positively moderated the association between risk disclosure and corporate value.

Applications of this study: The findings of this article can provide insights into the association between risk disclosure and corporate value and the moderating influence of the board of directors' independence on this relationship.

Novelty/Originality of this study: This study is particularly beneficial for understanding the importance of risk disclosure between the management and stakeholders as well as understanding the importance of the board of director composition in enhancing the influence of risk disclosure on corporate value. Moreover, this is the first study to investigate the moderating effect of board composition (represented by board independence) on the association between risk disclosure and corporate value.
\end{abstract}

Keywords: Risk Disclosure, Corporate Value, Board Independence, Corporate Governance, Jordan.

\section{INTRODUCTION}

Disclosure is considered an essential connection instrument between a company and its stakeholders. According to "International Financial Reporting Standards (IFRS)", the annual corporate financial report should contain financial statements, footnotes, management analysis, a management report, and other information that helps stakeholders build decisions (Elzahar \& Hussainey, 2012; Nahar et al., 2016).

Recently, risk disclosure (RD) has received more attention, has been considered an important issue of concern to the global business community, and has received overwhelming attention from stakeholders because it is the main tool to make risk information in the firm annual report transparent and is necessary to improve the risk management of a firm (Bravo, 2017; Ibrahim et al., 2019). Moreover, scandals in major companies (i.e. Enron Corp. in 2001 and WorldCom Corp. in 2002), as well as financial crises, such as the "Asian financial crisis of 1997" and "Global financial crisis of 2007-2008", have caused instability in financial markets and have driven to an increased interest in risk reporting (Khlif \& Hussainey, 2014). According to Acharya and Richardson (2009), the financial crises were caused by insufficient financial report transparency. Thus, risk disclosure is an important tool for improving the function of capital markets (Deumes, 2008).

Risk disclosure defined as "the publishing of any quantitative or qualitative information about uncertainties or risks facing the company". Therefore, risk disclosure is currently considered one of the most remarkable types of disclosure. Ntim and Osei (2011) argued that risk disclosure reduces information asymmetry problems by focusing on the potential risks that are related to investment and financing. Moreover, non-financial risks (e.g. wars, natural disasters, changes in regulation, and political instability) and financial risks (e.g. interest rates, exchange rates, and liquidity risks) contribute to volatility and uncertainty in the business environment and affect the sustainability of companies (Gjerald \& Lyngstad, 2015; Khlif \& Hussainey, 2014). Despite these effects, there is a lack of awareness about the importance of risk disclosure, which may lead to the misguidance of stakeholders in their investment decision-making. In addition, most investors only depend on the returns related to a determined investment project to make decisions and ignore other nonfinancial risks, which could result in massive losses or failures for the investors (Cabedo \& Tirado, 2004; Khlif \& Hussainey, 2014).

Previous studies have addressed risk disclosure as a renewed phenomenon, and it continues to be of significant academic interest in developed and developing countries due to the need to enhance financial statement transparency. Moreover, risk disclosure helps mitigate agency conflicts between managers and stakeholders, who can realize the company's risk level, introduce preferable future information, and enhance their confidence in annual reports (Abdullah et al., 2015; Bravo, 2017). 
Investors around the world have requested companies to refine their reporting on financial and non-financial risk information, which in turn, could decrease the risk of investing in the reporting firm and help investors make investment decisions and enhance corporate value (Abdullah et al., 2015). Miihkinen (2013) noted that risk information disclosure mitigates information asymmetry, which increases corporate value. However, many companies, particularly those in developing countries, refuse to increase risk information disclosure under the pretext that risk disclosure remains voluntary in most countries and this information usually involves sensitive information and endangers their business and economic condition. Consequently, the disagreement between companies and investors regarding risk disclosure motivated the examination of the association among risk disclosure and corporate value in developing markets.

The majority of prior empirical studies have addressed the direct impact of voluntary disclosure (i.e., risk information) on corporate value and demonstrated inconclusive and contrasting outcomes. These contrasting findings motivate future studies to search for other moderating variables that may affect the behaviors of management and influence the relationship between risk disclosure and corporate value to explore the relationship from multiple perspectives, especially those associated with board members who are responsible for disclosures. The composition of boards of directors (i.e. level of independence, size, number of meetings, and board diversity) can increase stakeholders' confidence, mitigate information asymmetry among market participants, and reduce risks (Al-Maghzom et al., 2016; Alkurdi et al., 2019; Makhlouf et al., 2018). Prior literature has argued that independent directors are able to encourage disclosure practices if they are able to truly execute their role (Ibrahim et al., 2019; Kiflee \& Khan, 2019).

Jordan is a valuable environment in which to study this relationship due to the voluntary condition of risk disclosure in Jordan. Furthermore, Jordanian firms are characterized by different characteristics, such as concentrated ownership and dominance of controlling shareholders (i.e., family control) (Haddad et al., 2015). In Jordan, 25\% of companies' shares are owned by families who dominate $23 \%$ of board seats in Jordanian listed firms, which implies that the board characteristics (i.e., level of board independence (BI)) may affect the level of voluntary disclosure, particularly risk disclosure (Makhlouf et al., 2018).

This paper contributes to the present literature with a new data set from a developing country (i.e. Jordan) that has several features that can support shed extra light on other institutional aspects in emerging markets. The findings of prior studies conducted in developed or in other emerging markets cannot be generalized to countries in the Middle East, including Jordan. Moreover, most of the previous literature (i.e. Abdullah et al., 2015; Bravo, 2017; Buckby et al., 2015; Elzahar \& Hussainey, 2012) used one-year data instead of multiple-year data, while the results of this study depended on a five-year data set. Moreover, prior studies have observed the direct influence of risk disclosure on corporate value. Thus, this study is the first attempt that investigates the moderating impact of the level of independence of boards of directors on the association among risk disclosure and corporate value.

The objective of this paper is to study the influence of risk disclosure on corporate value and investigate whether the impact of this relationship is moderated by the level of independence of boards of directors in Jordan. This paper will use the content analysis technique to measure risk disclosure as an independent variable, where Tobin's $Q$ will be used as a proxy to corporate value. Moreover, the board of directors' independence used as a moderator variable.

The next section addresses the literature review and the development of the hypotheses. Section 3 presents the sample of the study and describes data and the empirical methods of the study. Section 4 and 5 discuss the empirical results, while section 6 concludes the study.

\section{LITERATURE REVIEW}

\section{Risk Disclosure and Corporate value}

Previous studies, such as those by Abdullah et al. (2015); Elzahar and Hussainey (2012), indicated that joint consideration of disclosure theories is an assistive tool in understanding and interpreting disclosure practices in firms. The interest in researching information risk disclosure stems from a focus on "agency theory and signaling theory" as the main theoretical frameworks for risk disclosure studies (Abdullah et al., 2015; Elzahar \& Hussainey, 2012), where these theories provide richer insights for building the risk disclosure framework and each of these theories complements the other theory. "Signalling theory" focuses on managers' incentives to encourage management to reveal more financial risk information in annual reports to avoid opposite selection problems and introduce adequate information to convey certain signals to help stakeholders and potential beneficiaries (Dey et al., 2018). Most previous research has adopted "Signalling theory" to clarify why companies disclose voluntary information to stakeholders. Dey et al. (2018) argued that risk information disclosure is considered a sign of the strength of capital markets and mitigates information asymmetry that occurs between managers and stakeholders. Elzahar and Hussainey (2012) concluded that companies have an incentive to disclose more risk management information to stakeholders in addition to signaling that the companies are eligible to safeguard and make value for investors and to maximize corporate value.

According to agency theory, risk disclosure has a crucial role in the reduction of agency problems and agency conflicts, whereas managers tend to introduce appropriate information that will be valuable for users to ensure they are acting in the interest of stakeholders. Moreover, when management supplies credible risk information to investors and other stakeholders, information asymmetry is reduced, and the corporate value improves. Moreover, risk disclosure provides 
an environment of alignment of interests between stakeholders and management members and alignment between the interests of managers and interests of agents and, in turn, enhances the value of a company (Bhagat \& Bolton, 2013; Nahar et al., 2016).

Abdullah et al. (2015) noted that most firms sought to disclose more information voluntarily to improve the corporate value and maximize the trust of stakeholders and investors on the firm's performance. "Efficient-market hypothesis" proposes that a corporation's value should introduce beneficial information announced to the stakeholders (Elzahar \& Hussainey, 2012). However, numerous previous studies have emphasized the influence of voluntary risk disclosure on corporate value and demonstrated inconclusive findings. Nahar et al. (2016) noted that a potential explanation for the mixed results in prior literature might have been the inconsistent indices developed by authors to measure different factors. Based on data from a sample of 395 Malaysian firms for the year 2011, Abdullah et al. (2015) examined the relationship between risk management disclosure and firm performance in Malaysia via measurement of "Tobin's Q" and "the market to book value". The results indicated that risk management disclosure positively affects a firm's value.

Qiu et al. (2016) examined the effect of environmental and social disclosure as a component of voluntary disclosure; their findings indicate that social information disclosure significantly and positively affects corporate value, while environmental information disclosure does not have any influence. Bravo (2017) found that risk disclosure positively influences the corporate value and mediated by corporation reputation. In addition, risk disclosure is a positive sign to outside stakeholders that the managers are effectively acting in relation to risk management (Bravo, 2017). Healy and Palepu (2001) found that voluntary risk disclosure of governance procedures makes financial statement users more aware of the importance of a firm's risk resilience and stability by allowing assessment of a firm's risk, which may positively affect corporate value. Amir and Lev (1996) concluded that the integration between non-financial information and financial information in US firms tends to improve the value of a firm and indicates a positive relationship. In Australia, Buckby et al. (2015) concluded that the increase in the level of firm risk disclosure positively influences corporate value.

Based on a sample of 243 companies over a period of 9 years, Al-Akra and Ali (2012) constructed an index of 80 units of voluntary disclosure to study the effect of voluntary disclosure on the corporate value in Jordan. The index included "firm background information, information about directors, capital market data, product and service information, and research information." Their findings indicate that the voluntary disclosure positively affects corporate value, but that between growth and liquidity is not significant.

In contrast, Hassan et al. (2009) noted that the association between risk disclosure and corporate value is negative in Egyptian firms. However, multiple prior studies (i.e. Bokpin, 2013; Hassan, 2014) failed to reveal any significant impact of the association between risk disclosure and corporate value. Accordingly, the following hypothesis was formulated:

H1: "Risk disclosure has a positive association with corporate value".

\section{Moderating Role of the Level of Independence of Boards of Directors}

Risk disclosure continues to be of significant academic interest in developed and developing countries due to the need to enhance financial statement transparency and to solve the agency conflicts and introduce reliable annual reports. The contrasting findings of previous studies encourage this paper to study the intervening variables that may affect the behaviors of management and influence the relationship between risk disclosure and corporate value to explore the relationship from multiple perspectives, especially those associated with board members who are responsible for disclosures. The composition of boards of directors (i.e. level of independence) can increase stakeholders' confidence, mitigate information asymmetry among market participants, and reduce risks (Alkurdi et al., 2019; Makhlouf et al., 2018).

Board members are individuals with qualities that are unique to them and the organizations that they lead, which promotes the need to discover the impact of board composition on corporate value (Letting et al., 2012). Previous studies recognize the importance of the independence of boards of directors and their influence on the effectiveness of boards of directors as well as a corporate value. Moreover, independent members have diverse characteristics, backgrounds, and expertise, which improves decision-making and positively impacts corporate value (Makhlouf et al., 2017).

In the context of risk disclosure, Alkurdi et al. (2019); Ibrahim et al. (2019) concluded that the existence of independent directors supports the member's ability to reduce information asymmetry and agency problems between the managers and stakeholders and improves the quality of financial reporting. Consequently, independent directors have the power to pressure management to disclose more private information to gain more confidence in financial reporting (Alkurdi et al., 2019; Li et al., 2013). However, to the best of our knowledge, no studies have observed the interactive impact of board independence on risk disclosure and, consequently, on corporate value. Accordingly, the following hypothesis was formulated:

H2: "Board independence positively moderates the association between risk disclosure and corporate value". 


\section{METHODOLOGY}

\section{Sample selection and research model}

The sample of this study consisted of 15 banks listed on the Amman Stock Exchange (ASE) in 2018. Non-financial sectors have been excluded, Al-Maghzom et al. (2016) argued that financial firms (banks) are risk-oriented firms not similar to non-financial firms by nature. In addition, financial firms are managed by various series of rules and laws that make them totally different from companies in other sectors. Two banks were excluded due to invalid data. Thus, the final sample consisted of 13 banks. The annual reports were extracted from the ASE website. Unlike most of the previous literature (i.e. Abdullah et al., 2015; Bravo, 2017; Buckby et al., 2015; Elzahar \& Hussainey, 2012), which used one-year data instead of multiple-year data, this study included a sample of 13 banks with five-year data from 2014 to 2018. The study used regression analyses to examine the association between risk disclosure and bank value. The following model was the first model and aimed to investigate the association between risk disclosure (RD) and corporate value $(\mathrm{FV})$ :

$$
\text { Corporate value }=\alpha+\beta_{1} R D_{i t}+\beta_{2} \text { Control variable } i t+\varepsilon
$$

The second model aimed to reveal the moderating influence of BI on the association between risk disclosure and corporate value:

$$
\text { Corporate value }=\alpha+\beta_{1} R D_{i t}+\beta_{2} B I+\beta_{3} R D_{i t} * B I+\beta_{4} \text { Control variable }_{i t}+\varepsilon
$$

\section{Variable Measurements}

The corporate value was the dependent variable and measured by TQ. TQ is "a marketing measurement that considers the future outlook and reflects the value investors assigned to a firm's intangible assets based on predicted future revenue flow". Roll and Weston (2008) stated that TQ may be used as a proxy to measure a firm's growth opportunity. Moreover, Moreover, Jordan considered one of the favourable investment places in Arab countries and the MENA region. (Idris, 2012; Jaafar \& El-Shawa, 2009). Thus, TQ is an important indicator for prospective investors and current shareholders to help them make informed decisions.

Therefore, in this study, TQ was calculated as "the ratio of the market value of the firm to the book value of assets" (Amran, 2010; Darko et al., 2016). If TQ was greater than 1, the firm performed well in terms of its investment choices. Conversely, if TQ was lower than 1 (between 0 and 1), the firm's market value was lower than the value of its assets.

Risk disclosure (RD) was the independent variable. To measure the level of RD in Jordanian firms, the content analysis technique was used. Sentences were used as the element of analysis in this study because the sentence is more credible than words, which are difficult to explain without the context of a sentence (Elzahar \& Hussainey, 2012). Previous literature defined risk disclosure as "any opportunity or prospect, or of any hazard, danger, harm, threat or exposure, that has already impacted upon the company or may impact upon the company in the future or of the management of any such opportunity, prospect, hazard, harm, threat or exposure" (Abdullah et al., 2015; Elzahar \& Hussainey, 2012;

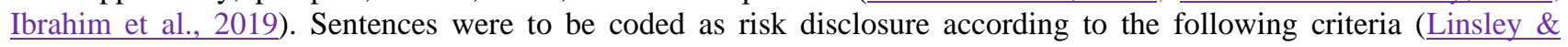
Shrives, 2006): 1. a sentence that explains a major risk faced by the company or how main risks were mitigated was treated as a risk disclosure sentence and 2. Any disclosure that was repeated was treated as a risk disclosure sentence. The disclosure must be explicit, not implied, and disclosure was not recognized as a risk disclosure when it was ambiguous (Bravo, 2017). In this study, the author coded sentences to calculate risk disclosure using an accumulated score for risk disclosure for each company by "counting the number of risk-related sentences in annual reports".

Moderating variable: The BI variable was computed as "the total number of independent directors on the board divided by the total number of board members" (Alkurdi et al., 2019; Ibrahim et al., 2019; Makhlouf et al., 2018).

Control variable: The researcher considered multiple control variables that may affect corporate value. The study depended on the literature and the availability of data in selecting the control variables. Therefore, the set of control variables in this study were firm size and leverage.

Table 1: Variable Definitions, Symbol, and measurement

\begin{tabular}{lcl}
\hline Definition & Symbol & Measurement \\
\hline Dependent variable & FV & $\begin{array}{l}\text { Tobin's Q “(common stock + value of preferred stock + book value of debt) } \\
\text { to Total assets" }\end{array}$ \\
\hline Corporate value & RD & $\begin{array}{l}\text { "The number of risk-related sentences (sentences that informs the reader of } \\
\text { any opportunity or prospect, or any hazard, danger, harm, threat, or exposure } \\
\text { that has influenced or may influence the firm in the future, or the management } \\
\text { of any of these cases" }\end{array}$ \\
\hline Independent variable & Risk Disclosure & "The total number of independent directors on the board divided by the total \\
\hline Moderating variable & BI & C Makhlouf et al.
\end{tabular}




\begin{tabular}{lll}
\hline & number of board members" \\
\hline Control Variables & & \\
\hline Firm Size & FS & "Natural logarithm of total assets" \\
\hline Leverage & LV & "Total liabilities to total assets" \\
\hline
\end{tabular}

\section{FINDINGS AND DISCUSSION}

\section{Descriptive Analysis}

Table 2 lists the descriptive statistics for study variables. The mean TQ was 1.28, which means that firm performance was good (TQ > 1). As shown in table 2, the average value of risk disclosure was 9.8, with a minimum of Zero and a maximum of 18. This outcome implies that the annual reports included approximately 10 sentences related to risks on average. Zero means that some firms' reports did not contain any risk-related sentences. The average BI was 59\%, which complies with the "Jordanian Corporate Governance Code" (JCGC) recommendations that one-third of board members should be independent directors. Nevertheless, the minimum value was $24 \%$, and the maximum value was $76 \%$, which indicates that some boards of directors were independent and some were not. Regarding the control variables, the average total asset value was 68,256,361 million Jordanian dinars, and the average leverage (FLEV) was approximately $0.39 \%$. Based on kurtosis and skewness, study variables are normally distributed except firm size, as recommended by Haniffa and Hudaib (2006), this research adopted a skewness of \pm 1.96 and kurtosis of \pm 3 to determine normality. When the firm size was not normally distributed, data transformation procedures were performed. In addition, the study was examined for multicollinearity between independent variables. A multicollinearity problem occurs if the "Variance inflation factor (VIF)" is greater than 10 (Hair et al., 2013). Based on the VIF, the results confirmed that the models of this study do not suffer from the multicollinearity problem.

Table 2: Descriptive Statistics for study variables

\begin{tabular}{cccccccc}
\hline Variables & Mean & Max. & Min. & Std. Deviation & Skewness & Kurtosis & VIF \\
\hline Tobin' Q & 1.28 & 3.92 & 0.1 & 0.74 & 1.38 & 2.49 & \\
\hline RD & 9.8 & 18 & 0 & 2.22 & -1.32 & -2.31 & 1.25 \\
\hline BI & 0.59 & 0.76 & 0.24 & 0.84 & 1.11 & 0.24 & 1.19 \\
\hline FS & 9.401 & 10.413 & 8.906 & 0.373 & 6.72 & 22.52 & 1.36 \\
\hline LV & 0.39 & 0.84 & 0.13 & 0.38 & 0.77 & 0.33 & 1.08 \\
\hline
\end{tabular}

\section{Diagnostic Tests}

To evaluate heteroscedasticity, a "Modified Wald test" was applied. As shown in Table 3, the findings indicated that the model suffered from heteroscedasticity $(\mathrm{p}<0.05)$. "Wooldridge test" was used to determine whether there was an "autocorrelation issue" in the data. The results indicated that autocorrelation was present (p-value < 0.05). Wooldridge (2012) suggested that the cluster robust standard errors technique should be employed to correct the issues of heteroscedasticity and autocorrelation.

Table 3: Heteroscedasticity and Autocorrelation Tests

\begin{tabular}{lll}
\hline & Direct model & $\begin{array}{l}\text { Moderating } \\
\text { model }\end{array}$ \\
\cline { 2 - 3 } & $\mathrm{Chi}^{2}\left(\mathrm{Prob}>\mathrm{chi}^{2}\right)$ & $\mathrm{Chi}^{2}\left(\right.$ Prob $\left.>\mathrm{chi}^{2}\right)$ \\
\hline Wald Test for Heteroscedasticity & $1.8(0.0000)$ & $1.1(0.0000)$ \\
\hline Wooldridge Test for Autocorrelation & $39.128(0.000)$ & $12.858(0.0013)$ \\
\hline
\end{tabular}

The panel data approach was adopted because it considers "unobservable heterogeneity by allowing for subject-specific variables". To analyze the "Panel data", there were three regression models that can be used (i.e., pooled OLS, fixed effect regression model (FEM), and a random-effects regression model (REM)). To choose between the FEM or POLS models, the "Breusch-Pagan Lagrange Multiplier (LM) test" was applied. The "Hausman test" was employed to select between the "REM and FEM" models. According to the LM test, if the $(p<0.05)$, the REM was more appropriate than the POLS model. According to Table 4, the p-value was significant ( $p<0.05$ ), which means that the REM was more appropriate than the POLS model. Thus, another test, (i.e. the Hausman test), was required to select between the "REM and FEM". The Hausman test results suggested the REM was more appropriate than the FEM and should be used if the p-value was not significant ( $p>0.05$ ). The outcome of the Hausman test indicated that the REM model fit our study since the p-value was not significant.

Table 4: Choosing Among the REM, FEM, and POLS model

\begin{tabular}{lll}
\hline & Direct model & $\begin{array}{l}\text { Moderating } \\
\text { model }\end{array}$ \\
\cline { 2 - 3 } & Chi2 (Prob > chi2) & Chi2 (Prob > chi2) \\
\hline LM test & $11.84(0.0011)$ & $11.98(0.0010)$ \\
\hline
\end{tabular}




\begin{tabular}{lll}
\hline Hausman Test & $43.56(0.8453)$ & $44.62(0.6592)$ \\
\hline
\end{tabular}

\section{Regression analysis}

In this study, a random-effects model was adopted according to the results of the Hausman test. Moreover, "clusterrobust standard errors" were employed to correct for "Heteroscedasticity and Autocorrelation" (Wooldridge, 2012). In this part, the findings and discussion for study models are described. Model 1 examined the direct association between risk disclosure and corporate value. Model 2 examined the moderating influence of BI on the association among risk disclosure and corporate value.

\section{Risk disclosure and corporate value (H1)}

The results from table 5 indicated an R2 value of $0.39 \%$. This result means that $39 \%$ of the variation in the corporate value could be interpreted by risk disclosure. Moreover, the F-statistic was highly significant $(\mathrm{p}<0.01)$, which indicates that the model sufficiently described the data. The outcomes show that the association between risk disclosure and company value was negative and significant. This result implies that an increase in risk disclosure decreases company value. The negative result could be imputed to the nature of ownership structure (i.e. family ownership). Makhlouf et al. (2017) noted that $25 \%$ of companies' shares are owned by families. Such families may depend on their authority to influence managers' decisions and dampen monitoring process and may affect the nature of voluntary information disclosure related to risk.

The outcomes of this study are inconsistent with the signaling and agency theories' perspective, which suppose that risk disclosure positively affects corporate value. Therefore, hypothesis 1 , which predicted a positive association between corporate value and risk disclosure, was not supported. This result supports the outcomes of several previous empirical studies (i.e., Hassan et al., 2009; Kamaruzaman et al., 2019) that found an adverse association between risk disclosure and corporate value. However, these results contrast those reported in some previous studies (i.e. Al-Akra \& Ali, 2012; Bravo, 2017; Buckby et al., 2015).

Table 5: The Association between Risk Disclosure and TQ

\begin{tabular}{|c|c|c|c|c|}
\hline Variables & Predict sign & Coeff. & t-Statistic & P-value \\
\hline Con- & & 0.294 & 1.761 & 0.0788* \\
\hline RD & + & -0.285 & -2.199 & $0.0284 * *$ \\
\hline FS & & 0.211 & 0.691 & 0.0894* \\
\hline FL & & 0.621 & 0.250 & 0.8027 \\
\hline $\mathrm{R}^{2}$ & \multicolumn{4}{|c|}{0.39} \\
\hline F-statistic & \multicolumn{4}{|c|}{$18.645 * * *$} \\
\hline
\end{tabular}

\section{Moderating effect of Board independence (BI)}

Consistent with most previous studies, the hierarchical regression model was used to study the moderating impact of the level of independence of boards of directors on the association among risk disclosure and corporate value. In the hierarchical regression model, the data are treated in three separate models. The model I is for the regression of the independent variable (risk disclosure) and control variables. In model II, the moderator variable (BI), is regressed with the independent variable (RD) and dependent variables (TQ). Model III included the interaction variable (RD*BI).

Table 6: The Moderating Influence of Board Independence on the Association between Risk Disclosure and Tobin's Q

\begin{tabular}{|c|c|c|c|c|c|c|}
\hline \multirow[b]{2}{*}{ Variables } & \multicolumn{2}{|c|}{ First Model } & \multicolumn{2}{|c|}{ Second Model } & \multicolumn{2}{|c|}{ Third Model } \\
\hline & $\begin{array}{l}\text { Coff. } \\
\text { t-Stat. }\end{array}$ & P-value & $\begin{array}{l}\text { Coff. } \\
\text { t-Stat. }\end{array}$ & P-value & $\begin{array}{c}\text { Coff. } \\
\text { t-Stat. }\end{array}$ & P-value \\
\hline Con- & $\begin{array}{l}0.294 \\
1.761\end{array}$ & $0.0788^{*}$ & $\begin{array}{l}2.118 \\
0.658\end{array}$ & $0.0129 * *$ & $\begin{array}{l}1.134 \\
0.068\end{array}$ & $0.0451 * *$ \\
\hline $\mathrm{RD}$ & $\begin{array}{l}-0.285 \\
-2.199\end{array}$ & $0.0284 * *$ & $\begin{array}{l}-3.207 \\
-1.697\end{array}$ & $0.0095 * *$ & $\begin{array}{l}-0.209 \\
-1.647\end{array}$ & $0.0034 * * *$ \\
\hline BI & & & $\begin{array}{l}0.395 \\
2.896\end{array}$ & $0.0240 * *$ & $\begin{array}{l}0.267 \\
2.790\end{array}$ & $0.0056 * * *$ \\
\hline $\mathrm{RD} * \mathrm{BD}$ & & & & & $\begin{array}{l}0.750 \\
3.335\end{array}$ & $0.0326 * *$ \\
\hline FSIZE & $\begin{array}{l}0.211 \\
0.691 \\
\end{array}$ & $0.0894^{*}$ & $\begin{array}{l}0.635 \\
0.068 \\
\end{array}$ & $0.0439 * *$ & $\begin{array}{l}0.932 \\
0.050 \\
\end{array}$ & $0.0393 * *$ \\
\hline FLEV & $\begin{array}{l}0.621 \\
0.250\end{array}$ & 0.8027 & $\begin{array}{l}-0.834 \\
-2.220\end{array}$ & 0.7100 & $\begin{array}{l}-0.942 \\
-0.258\end{array}$ & 0.6154 \\
\hline $\mathrm{R}^{2}$ & & & & & & \\
\hline
\end{tabular}




$\begin{array}{llll}\text { F-statistic } & 18.645 * * * & 17.994 * * * & 17.888 * * *\end{array}$

$*, * *, * * *$ significance at the $10 \%, 5 \%, 1 \%$, levels

$\mathrm{TQ}=$ Tobin's $\mathrm{Q}, \mathrm{RD}=$ Risk disclosure. $\mathrm{BI}=$ Board independence, $\mathrm{RD} * \mathrm{BI}=$ interaction effect between $\mathrm{RD}$ and $\mathrm{BI} . \mathrm{FS}=$ Firm size, FL= Leverage.

Table 6demonstrates the findings for the moderating influence of BI on the association among risk disclosure and corporate value (TQ). The outcomes in the model I indicate that there was a significant negative association between RD and Tobin's Q (TQ). When BI was entered into the regression in model II, the findings indicated that risk disclosure had a significant and negative association with TQ; this effect occurred because BI influences risk disclosure. Regarding the moderating variable (BI), the results revealed a positive association between BI and TQ. When risk disclosure has interacted with $\mathrm{BI}(\mathrm{RD} * \mathrm{BI})$ in model III, some interesting results were obtained; the coefficient became positive and significant. This finding means that BI positively moderated the association among risk disclosure and TQ and shows that the presence of independent members on the board can improve the relationship between risk disclosure and corporate value in Jordanian banks. Therefore, hypothesis 2, which predicted that BI positively impacts the association between RD and TQ, was supported.

In general, some notable outcomes were obtained. The positive findings imply that the presence of independent members can strengthen the association between risk disclosure and the value of Jordanian banks. In other words, when independent members are present on the board of directors, the board is able to influence corporate value so that it becomes more efficient (Alkurdi et al., 2019). This finding is consistent with agency perspective, which recommends that independent members have the authority to pressure management to disclose more private information to gain more confidence in financial reporting and reduce information asymmetry (Al-Maghzom et al., 2016; Ibrahim et al., 2019).

\section{CONCLUSION}

This study contributed to current risk disclosure literature as the first to investigate if the level of independence of boards of directors moderates the relationship between RD and corporate value (TQ). Although the direct relationship results indicate that the relationship between RD and corporate value is negative, the findings demonstrated that board independence plays a positive and vital role in improving the relationship between risk disclosure and corporate value. This finding encourages shareholders to choose more independent members to represent them on the board. Moreover, this finding benefits all stakeholders because the presence of independent members can increase stakeholders' confidence in annual reporting.

\section{LIMITATION AND STUDY FORWARD}

This paper has a few limitations. First, non-financial companies were eliminated because these companies are regulated by a different group of rules. Consequently, it would be beneficial for further studies to investigate the relationship between risk disclosure and corporate value in non-financial firms. Second, this study depended only on information published in annual reports, while itis possible to obtain risk information from other channels, such as the prospectus, press releases, interim reports, and firm websites. In addition to annual reports, future studies can examine risk disclosure information from other sources. Third, this study focused only on the effect of BI as a moderator variable and ignores other qualities of the board of directors, for instance, board diversity, board meetings, and duality, or focus on the ownership type, for instance, family ownership or director ownership.

\section{ACKNOWLEDGMENT}

"The authors are grateful to Isra University/ Jordan for the financial support granted to this research project."

\section{AUTHORS CONTRIBUTION}

"Mohammed Makhlouf is responsible for the paper preparation, design the conceptual framework, analysed the data, and corresponding to the publisher. Yazan Oroud assist in data processing. Mohammed Soda contributed to data collection".

\section{REFERENCES}

1. Abdullah, M., Abdul Shukor, Z., Mohamed, Z. M., \& Ahmad, A. (2015). Risk management disclosure: A study on the effect of voluntary risk management disclosure toward corporate value. Journal of Applied Accounting Research, 16(3), 400-432. https://doi.org/10.1108/JAAR-10-2014-0106

2. Acharya, V. V., \& Richardson, M. P. (2009). Restoring Financial Stability: How to Repair a Failed System (Vol. 542). John Wiley \& Sons. https://doi.org/10.1002/9781118258163

3. Al-Akra, M., \& Ali, M. J. (2012). The value relevance of corporate voluntary disclosure in the Middle-East: The case of Jordan. Journal of Accounting and Public Policy, 31(5), 533-549. https://doi.org/10.1016/j.jaccpubpol.2011.10.007

4. Al-Maghzom, A., Hussainey, K., \& Aly, D. A. (2016). Corporate governance and risk disclosure: Evidence from Saudi Arabia. Corporate Ownership and Control Journal, 13(2). https://doi.org/10.22495/cocv13i2p14

5. Alkurdi, A., Hussainey, K., Tahat, Y., \& Aladwan, M. (2019). The impact of corporate governance on risk disclosure: Jordanian evidence. Academy of Accounting and Financial Studies Journal, 23(1), 1-16. 
6. Amir, E., \& Lev, B. (1996). Value-relevance of nonfinancial information: The wireless communications industry. Journal of accounting and economics, 22(1-3), 3-30. https://doi.org/10.1016/S0165-4101(96)00430-2

7. Amran, N. (2010). Corporate Governance Mechanisms, Succession Planing And Firm Performance: Evidence From Malaysian Family And Nonfamily-Controlled Companies [Thesis, Universitu Utara Malaysia].

8. Bhagat, S., \& Bolton, B. (2013). Director Ownership, Governance, And Performance. Journal of Financial and Quantitative Analysis, 48(01), 105-135. https://doi.org/10.1017/S0022109013000045

9. Bokpin, G. (2013). Determinants and value relevance of corporate disclosure: Evidence from the emerging capital market of Ghana. Journal of Applied Accounting Research, 14(2), 127-146. https://doi.org/10.1108/09675421311291883

10. Bravo, F. (2017). Are risk disclosures an effective tool to increase corporate value? Managerial and Decision Economics, 38(8), 1116-1124. https://doi.org/10.1002/mde.2850

11. Buckby, S., Gallery, G., \& Ma, J. (2015). An analysis of risk management disclosures: Australian evidence. Managerial Auditing Journal, 30(8/9), 812-869. https://doi.org/10.1108/MAJ-09-2013-0934

12. Cabedo, J. D., \& Tirado, J. M. (2004). The disclosure of risk in financial statements. Accounting Forum. https://doi.org/10.1016/j.accfor.2003.10.002

13. Darko, J., Aribi, Z. A., Uzonwanne, G. C., Eweje, G., \& Eweje, G. (2016). Corporate Governance: The Impact Of Director And Board Structure, Ownership Structure And Corporate Control On The Performance Of Listed Companies On The Ghana Stock Exchange. Corporate Governance: The International Journal of Business in Society, 16(2). https://doi.org/10.1108/CG-11-2014-0133

14. Deumes, R. (2008). Corporate risk reporting: A content analysis of narrative risk disclosures in prospectuses. The Journal of Business Communication (1973), 45(2), 120-157. https://doi.org/10.1177/0021943607313992

15. Dey, R., Hossain, S., \& Rezaee, Z. (2018). Financial risk disclosure and financial attributes among publicly traded manufacturing companies: Evidence from Bangladesh. Journal of Risk and Financial Management, 11(3), 50. https://doi.org/10.3390/jrfm11030050

16. Elzahar, H., \& Hussainey, K. (2012). Determinants of narrative risk disclosures in UK interim reports. The Journal of Risk Finance, 13(2), 133-147. https://doi.org/10.1108/15265941211203189

17. Gjerald, O., \& Lyngstad, H. (2015). Service risk perceptions and risk management strategies in business-tobusiness tourism partnerships. Tourism management perspectives, 13, 7-17. https://doi.org/10.1016/j.tmp.2014.10.002

18. Haddad, A. E., AlShattarat, W. K., AbuGhazaleh, N. M., \& Nobanee, H. (2015). The Impact Of Ownership Structure And Family Board Domination On Voluntary Disclosure For Jordanian Listed Companies. Eurasian Business Review, 5(2), 203-234. https://doi.org/10.1007/s40821-015-0021-5

19. Hair, J. F., Black, W. C., Babin, B. J., \& Anderson, R. E. (2013). Multivariate Data Analysis (7th ed.). Pearson Education Limited. https://books.google.com.my/books?id=VvXZnQEACAAJ

20. Haniffa, R., \& Hudaib, M. (2006). Corporate Governance Structure and Performance of Malaysian Listed Companies. Journal of Business Finance \& Accounting, 33(7-8), 1034-1062. https://doi.org/10.1111/j.14685957.2006.00594.x

21. Hassan, N. (2014). Investigating the impact of firm characteristics on the risk disclosure quality. International Journal of Business and Social Science, 5(11).

22. Hassan, O. R., Peter, Giorgioni, G., \& Power, D. (2009). The value relevance of disclosure: Evidence from the emerging capital market of Egypt. The International Journal of Accounting, 44(1), 79-102. https://doi.org/10.1016/j.intacc.2008.12.005

23. Healy, P. M., \& Palepu, K. G. (2001). Information asymmetry, corporate disclosure, and the capital markets: A review of the empirical disclosure literature. Journal of accounting and economics, 31(1-3), 405-440. https://doi.org/10.1016/S0165-4101(01)00018-0

24. Ibrahim, A., Habbash, M., \& Hussainey, K. (2019). Corporate governance and risk disclosure: evidence from Saudi Arabia. International Journal of Accounting, Auditing and Performance Evaluation, 15(1), 89-111. https://doi.org/10.1504/IJAAPE.2019.096748

25. Idris, M. I. I. (2012). The Impact Of Ownership Structure And External Audit On Accruals And Real Activities Earnings Management In Jordan University of Gloucestershire].

26. Jaafar, A., \& El-Shawa, M. (2009). Ownership concentration, board characteristics and performance: evidence from Jordan. In S. U. Mathew Tsamenyi (Ed.), Accounting in Emerging Economies (Vol. 9, pp. 73-95). Emerald Group Publishing Limited. https://doi.org/10.1108/S1479-3563(2009)0000009005

27. Kamaruzaman, S. A., Ali, M. M., Ghani, E. K., \& Gunardi, A. (2019). Ownership structure, corporate risk disclosure and corporate value: a Malaysian perspective. International Journal of Managerial and Financial Accounting, 11(2), 113-131. https://doi.org/10.1504/IJMFA.2019.099766

28. Khlif, H., \& Hussainey, K. (2014). The association between risk disclosure and firm characteristics: a metaanalysis. Journal of Risk Research, 19(2), 181-211. https://doi.org/10.1080/13669877.2014.961514

29. Kiflee, A. K. R. B., \& Khan, M. N. A. B. A. (2019). Relationship between Corporate Governance and Risk Disclosure Practice from Malaysia Perspective. KnE Social Sciences, 66-89-66-89.

30. Letting, N., Aosa, E., \& Machuki, V. (2012). Board Diversity and Performance of Companies Listed in Nairobi Stock Exchange. International Journal of Humanities and Social Science, 2(11), 172-182. 
31. Li, H., Jahera Jr, J. S., \& Yost, K. (2013). Corporate risk and corporate governance: another view. Managerial Finance, 39(3), 204-227. https://doi.org/10.1108/03074351311302773

32. Linsley, P. M., \& Shrives, P. J. (2006). Risk reporting: A study of risk disclosures in the annual reports of UK companies. The British Accounting Review, 38(4), 387-404. https://doi.org/10.1016/j.bar.2006.05.002

33. Makhlouf, M. H., Laili, N. H., Ramli, N. A., Al-Sufy, F., \& Basah, M. Y. (2018). Board of directors, firm performance and the moderating role of family control in Jordan. Academy of Accounting and Financial Studies Journal, 22(5), 1-15.

34. Makhlouf, M. H., Laili, N. H., Ramli, N. A., \& Basah, M. Y. (2017). Board of Directors' Effectiveness and Firm Performance: Evidence from Jordan. Research Journal of Finance and Accounting, 8(18), 23-34.

35. Miihkinen, A. (2013). The usefulness of firm risk disclosures under different firm riskiness, investor-interest, and market conditions: New evidence from Finland. Advances in Accounting, 29(2), 312-331. https://doi.org/10.1016/j.adiac.2013.09.006

36. Nahar, S., Azim, M., \& Anne Jubb, C. (2016). Risk disclosure, cost of capital and bank performance. International Journal of Accounting \& Information Management, 24(4), 476-494. https://doi.org/10.1108/IJAIM-02-2016-0016

37. Ntim, C. G., \& Osei, K. A. (2011). The Impact of Corporate Board Meetings on Corporate Performance in South Africa. African Review of Economics and Finance 2(2), 83-103.

38. Qiu, Y., Shaukat, A., \& Tharyan, R. (2016). Environmental and social disclosures: Link with corporate financial performance. The British Accounting Review, 48(1), 102-116. https://doi.org/10.1016/j.bar.2014.10.007

39. Roll, R., \& Weston, J. (2008). Average and Marginal Tobins $q$ as Indicators of Future Growth Opportunities, Expected Return, and Risk.

40. Wooldridge, J. M. (2012). Introductory Econometrics: A Modern Approach ( 5th ed.). Cengage Learning.

41. Al-Maghzom, A., Hussainey, K., \& Aly, D. A. (2016). Corporate governance and risk disclosure: Evidence from Saudi Arabia. Corporate Ownership and Control Journal, 13(2). https://doi.org/10.22495/cocv13i2p14

42. Alkurdi, A., Hussainey, K., Tahat, Y., \& Aladwan, M. (2019). The impact of corporate governance on risk disclosure: Jordanian evidence. Academy of Accounting and Financial Studies Journal, 23(1), 1-16.

43. Ibrahim, A., Habbash, M., \& Hussainey, K. (2019). Corporate governance and risk disclosure: evidence from Saudi Arabia. International Journal of Accounting, Auditing and Performance Evaluation, 15(1), 89-111. https://doi.org/10.1504/IJAAPE.2019.096748 